Pesquisa e Reflexão em Educação Básica

\title{
Jovens de terreiros no chão da escola: tensões e resistências
}

Cláudia Maria de Jesus Castro ${ }^{1}$

\begin{abstract}
Resumo:
Este artigo é um recorte de uma pesquisa de mestrado que investigou os jovens de terreiros e o espaço escolar. Essa investigação se estabeleceu a partir da articulação entre o campo educacional e religioso e, para isso, traz algumas reflexões teórico-conceituais sobre juventude e a relação com a escola e a religião. Entende-se que a juventude como um grupo social e diverso que, embora seja parametrizado por uma faixa etária, produz juventudes diferentes a partir da relação entre o mundo objetivo e o subjetivo. Apesar de uma aparente unidade, a juventude é compreendida na sua pluralidade quando se considera a classe, a etnia, o gênero, a raça, o econômico e a religião como elementos importantes na sua constituição. Os resultados da pesquisa apontam que os jovens de terreiros constroem suas estratégias de resistência ao preconceito no espaço escolar, mas estas não garantem a transformação do campo ou no reconhecimento legítimo das suas crenças. Conclui-se que o papel da escola é fazer a mediação das tensões e possibilitar a ampliação do repertório juvenil quanto à pluralidade e diversidade cultural religiosa.
\end{abstract}

\section{Palavras- chave:}

Jovens. Terreiro. Escola.

\section{Young people from terreiros on the school floor: tensions and resistances}

\begin{abstract}
This article is an excerpt from a master's research that investigated young people from terreiros and the school space. This investigation was established from the articulation between the educational and religious fields and, for that, it brings some theoretical-conceptual reflections on youth and the relationship with school and religion. It is understood that youth as a social and diverse group that, although parameterized by an age group, produces different youths based on the relationship between the objective and the subjective world. Despite an apparent unity, youth is understood in its plurality when considering class, ethnicity, gender, race, economics and religion as important elements
\end{abstract}

\footnotetext{
1 Mestra em Educação, Pedagoga na Secretaria Estadual de Educação de Goiás. E-mail: claudia-mjc@ @otmail.com. ORCID iD: https://orcid.org/0000-0002-5784-4090.

2 Doutora em Educação, Professora da PUC Goiás. E-mail: cavalcante.70@hotmail.com. ORCID iD: https://orcid.org/00000001-9521-6784.
} 
in its constitution. The results of the research show that young people from terreiros build their strategies to resist prejudice in the school space, but these do not guarantee the transformation of the countryside or the legitimate recognition of their beliefs. It is concluded that the role of the school is to mediate tensions and enable the expansion of the youth repertoire regarding plurality and religious cultural diversity.

Keywords: Youth. Terreiro. School.

\section{Jóvenes de terreiros en el suelo de la escuela: tensiones y resistências}

Resumen: Este artículo es un extracto de una investigación de máster que investigó a los jóvenes de terreiros y el espacio escolar. Esta investigación se estableció a partir de la articulación entre los campos educativo y religioso y, para ello, aporta algunas reflexiones teórico-conceptuales sobre la juventud y la relación con la escuela y la religión. Se entiende a la juventud como un grupo social y diverso que, aunque parametrizado por un grupo de edad, produce diferentes jóvenes en función de la relación entre el mundo objetivo y el subjetivo. A pesar de una aparente unidad, la juventud es entendida en su pluralidad al considerar la clase, la etnia, el género, la raza, la economía y la religión como elementos importantes en su constitución. Los resultados de la investigación muestran que los jóvenes de terreiros construyen sus estrategias para resistir los prejuicios en el espacio escolar, pero estos no garantizan la transformación del campo ni el legítimo reconocimiento de sus creencias. Concluimos que el papel de la escuela es mediar tensiones y permitir la expansión del repertorio juvenil en cuanto a pluralidad y diversidad cultural religiosa.

Palabras clave: Jóvenes. Terreiro. Escuela.

\section{Introdução}

Este estudo resulta de uma pesquisa sobre jovens de terreiros e sua relação com a escola, um campo de investigação pouco debatido no campo educacional e carece de visibilidade crítica e propositiva no âmbito das políticas educacionais.

Deste modo, fazer o debate da relação entre juventude, educação e religião de matrizes africanas pressupõe transitar por distintos campos do conhecimento a fim de abarcar a complexidade do tema de forma interdisciplinar. Nesse sentido, o aporte teórico sobre a juventude se constitui na sociologia da juventude, como um objeto de estudo dessa área de conhecimento, com a contribuição de autores na discussão e na apreensão de conceitos que nos ajudam a pensar a juventude no seu modo plural e diverso, complexo e singular, portanto, histórico, social e cultural.

Dayrell (2003, p. 42) enfatiza que "a juventude constitui um momento determinado, mas não se reduz a uma passagem; ela assume uma importância em si mesma”. É parametrizada por uma faixa etária mas definida por este recorte visto que as representações das idades são culturais também. Abramo (2003, p. 43) chama a atenção para a importância de tratar a juventude no plural: "precisamos falar de juventudes, no plural, e não de juventude, no singular, para não esquecer as diferenças e desigualdades que atravessam esta condição". Na perspectiva de Pais (1990), a análise sociológica da juventude perpassa a discussão da dicotomia unidade e diversidade em que o primeiro reconhece a juventude como uma massa homogênea e o segundo leva em consideração atributos como gênero, etnia, classe social, entre outros como elementos importantes na configuração das culturas juvenis.

Assim, o crescente interesse pelos estudos da juventude no Brasil a partir dos anos 1980 sinaliza a importância deste grupo social para a comunidade científica bem como para as políticas públicas sociais, educacionais, entre outras. A investigação da juventude sob a perspectiva das culturas juvenis pressupõe uma análise que transcende a condição de estudante e busca apreender 
as culturas espontâneas as quais aderem e produzem modos de ser, sentir e agir no mundo. Dentre as diversas instâncias e espaços em que os jovens transitam, a religião tem-se configurado como um desses espaços que dão sentido ao modo de ser jovem na contemporaneidade. Contudo nem toda religião é socialmente aceita como legítima. Ao contrário, percebe-se um aumento exponencial de adesão a religiões Neopentecostais e um desprestígio de religiões de matrizes africanas a ponto de serem atacadas violentamente tanto no espaço público como nos terreiros de candomblé, como registradas e veiculadas pelas mídias.

É sobre esses jovens que possuem vínculo com o Candomblé que este estudo se insere, ou seja, participaram da pesquisa, com abordagem qualitativa, duas jovens e quatro jovens de terreiros, estudantes ou egressos da educação pública, trabalhadores e/ou desempregados, localizado na Região Metropolitana de Goiânia, que já sofreram ou não preconceito por conta da sua religião no espaço escolar.

Ressalta-se que o preconceito que se revela às religiões de matrizes africanas não é dos tempos atuais. Historicamente, os praticantes dessas religiões têm sofrido perseguições e ataques constantes. Contudo, diante desse cenário geral de atitudes negativas, discriminatórias à religião do candomblé, e aos praticantes, Freitas (2015, p. 621) afere que

Considerando que, além de negros, pobres e moradores em periferias, estes jovens são integrantes de religiões negativamente representadas por conta de seus rituais de sacrifícios, possessão e magia - o que promove a ideia de uma dupla estereotipia ou uma meta clicherização que contribui, eficazmente, para o alijamento das representações positivas, assim como legitima a constituição de ações excludentes e discriminatórias contra esta expressiva parcela da população.

Diante dessa configuração, é recente no cenário brasileiro, a presença de iniciativas que têm debatido sobre questões específicas do campo da juventude e do pertencimento às religiões de matriz africana. Com efeito, foi sancionada e decretada a Lei 10.639, em 2003, que tornou obrigatório o ensino de História e Cultura Afro-Brasileiras em escolas públicas e privadas, no ensino fundamental e médio. Apesar da obrigatoriedade do cumprimento da lei pelos sistemas de ensino, o que se observa ainda é o descumprimento quanto à aplicabilidade desta Lei Federal. Essas revelações ratificam os estudos de Bourdieu (2014, p. 46),

É provavelmente por um efeito de inércia cultural que continuamos tomando o sistema escolar como um fator de mobilidade social, segundo a ideologia da 'escola libertadora', quando, ao contrário, tudo tende a mostrar que ele é um dos fatores mais eficazes de conservação social, pois fornece a aparência de legitimidade às desigualdades sociais, e sanciona a herança cultural e o dom social tratado como dom natural.

Neste sentido, a escola como espaço de culturas e diversidade sócio cultural que se entrecruzam e tensionam as normas e os sensos comuns que se constituem no espaço escolar que esses jovens confrontam cotidianamente o modo se ser jovem de terreiro, que trazem marca do seu grupo religioso, seja na vestimenta, nos adereços, nas crenças, nas representações religiosas, entre outros aspectos que constituem suas identidades. Por um lado, a cultura escolar opera segundo a cultura dominante (BOURDIEU, 2014) é agravada pela conjuntura conservadora que se configura atualmente com a legitimação de Escolas Cívico-Miltares e projetos como Escola da Mordaça e Escola Sem Partido; por outro, os agentes que compõem o espaço escolar, neste caso, os jovens de terreiros tensionam os consensos, os nomos e resistem às lógicas das escolas conservadoras. Foi a partir desse contexto descrito que se construiu o tema jovens no terreiro no chão da escola. Para a apresentação dessa pesquisa, o presente artigo está organizado em três sessões que discutem juventude e religião, o campo escolar e o campo religioso e as experiências dos jovens de terreiros no espaço escolar. Ao final, tecemos considerações sobre o tema. 


\section{Juventude e religião}

É a partir do entendimento da juventude como um grupo social e diverso que este estudo compreende que, embora sejam parametrizados por uma faixa etária, os jovens produzem juventudes diferentes a partir das relações entre o mundo objetivo e o subjetivo. Apesar de sua aparente unidade, a juventude é entendida na sua heterogeneidade, levando-se em consideração o gênero, a classe, a etnia, a raça e a religião como elementos constitutivos da juventude.

Pais (1990) faz a distinção entre duas epistemologias que perpassam o conceito de juventude que orientam as práticas sociais: a aparente unidade e a diversidade. Para Pais (1990), a juventude como aparente unidade é concebida como um conjunto social mais uniforme e homogêneo, pois o principal aspecto constitui-se por indivíduos que fazem parte de uma mesma "fase da vida", prevalecendo a busca de fatores que caracterizam esta etapa em termos de faixa etárias. Urteaga (2011) corrobora com essa ideia ao enfatizar que ao longo da história da sociedade, o que foi concebido como uma construção sociocultural do que é o juvenil, por sua vez, tem tematizado os jovens como sujeitos passivos, que devem buscar a formação e preparação para uma vida adulta no futuro. Já na segunda vertente, a diversidade (PAIS, 1990), a juventude é balizada como um conjunto social diversificado, plural, e que apresenta distintas culturas juvenis, contextualizadas em diferentes pertenças de classe, diferentes situações econômicas, dentre outras.

Complementando essa ideia, Urteaga (2011) comenta que este modo de entender a juventude a partir da perspectiva das culturas juvenis proporciona um importante viés interpretativo da heterogeneidade cultural dos jovens na construção de novos espaços sociais, em que eles constroem suas próprias normas, expressões culturais, ritos, haja vista, modos de ser que os distinguem do mundo adulto. Para a autora:

Culturas juvenis foi uma noção vital para reintroduzir o sujeito jovem como ator e poder fazer ouvir as vozes dos segmentos juvenis marginalizados da investigação social. Feixa, Reguillo, Marcial, Urteaga e muitos outros investigadores enfatizam a importância de ler as representações e práticas juvenis como metáforas da mudança social, rompendo com as interpretações lineares e 'fazendo falar' o conjunto de elementos com os quais os jovens interagem - desde diferentes âmbitos e localizando-se em múltiplas dimensões como classe, gênero, geração, etnia, território, espaço urbano-rural - e com os quais constroem novas formas e concepções de política, de relações sociais e afetivas, de cultura etc. (URTEAGA, 2011, p. 19).

Ademais, a juventude deve ser entendida como um mosaico que se refere à pluralidade de uma população com inúmeros e não somente um modo de representar esta condição e situação social na sociedade contemporânea. No entendimento de Abramo (2012), é preciso falar de juventudes, no plural, e não apenas de juventude, no singular, para não esquecer as situações relacionadas às diferenças e desigualdades sociais.

Logo, dentro dessa pluralidade, a religião desempenha um papel importante na constituição das culturas juvenis e pode ser compreendida tanto como espaços de socialização, em que habitus são inculcados e constituídos na formação das identidades, quanto espaços de sociabilidade que dão sentidos às experiências juvenis. A adesão de jovens às distintas religiões na contemporaneidade é um campo de investigação de pesquisadores da juventude (NOVAES, 2004, 2011; SOFIATI et al., 2016).

A ordem global atual proporcionou que novos e velhos fundamentalismos passassem a interagir na engrenagem de um mundo religioso multifacetado, o qual apresenta uma intensa mobilidade de crenças, com expressivo número de pessoas circulando de uma religião a outra ou participando do duplo pertencimento, "cuja adesão religiosa permite rearranjos provisórios entre crenças e ritos sem fidelidades institucionais" (NOVAES, 2011, p. 289). E os jovens têm sido o público alvo das 
religiões de diferentes matrizes visto que houve um aumento significativo da população jovem nas últimas décadas bem como a visibilidade desse grupo social, como destaca Sofiati et al. (2016, p. 66), "ao longo das últimas décadas: 8,2 milhões, em 1940; 10,4 milhões, em 1980; 28,5 milhões, em 1990; 34,0 milhões, em 2000; e 34,2 milhões, em 2010". A juventude representa cerca de 25\% da população brasileira e sua inserção social na sociedade civil vem ganhando notoriedade "nos discursos e nas pautas políticas" (ABRAMO, 2012, p. 38).

Segundo a Secretaria Nacional da Juventude (SNJ, 2014), houve uma expressiva adesão juvenil aos valores religiosos. Conforme Sofiati et al. (2016, p. 90), houve, entre os jovens, um aumento do número de evangélicos e dos que não têm religião, ao passo que diminuiu a proporção de católicos. Os dados dessa pesquisa registraram as seguintes porcentagens: $55 \%$ são católicos, $29 \%$ evangélicos e $2 \%$ espíritas. Por outro lado, 3\% não seguem nenhuma religião e 15\% acreditam em Deus.

Assim, a religião ganha credibilidade perante o olhar da juventude desse século, que busca a pertença religiosa e com qual instituição ela mais se identifica, pois parece que os jovens têm dado um novo sentido à religião e valorizam mais a experiência pessoal do que a materialização na instituição. Nesse sentido, Novaes (2011, p. 271) diz que:

Nessa geração nada pode ser visto como muito estável, pois o que mais a caracteriza é a disponibilidade para a experimentação, o que ocorre também no campo religioso são os jovens o que mais transitam entre vários pertencimentos sociais e espirituais.

Desse modo, os dados da Pesquisa Religião, Cultura e Política entre juventude de Minas Gerais, desenvolvida em 2004 por Tavares e Camurça, revelam que a religião ganha maior notoriedade entre jovens negros, mulheres e membros de família com pouco grau de instrução e/ou moradores da periferia. A pesquisa também observa que no decorrer da trajetória escolar, grande parte dos jovens tende a passar por um processo de rearranjos de suas crenças religiosas. Os autores ainda advertem que: A "experiência geracional" de nossos jovens estudantes sugere fortemente que a religião continue a atuar sobre a vida, a ser fonte de sentido e de experiência, mas não necessariamente e unicamente sob a forma exclusivamente formal da religião institucional e tradicional ou do mero produto de consumo (TAVARES; CAMURÇA, 2004, p. 25).

Alguns traços marcantes da sociedade moderna vêm se descortinando nas décadas correntes. Um deles é o pluralismo religioso que contribui para dissolução, enfraquecimento de sistemas estruturais pelos novos concorrentes dentro do campo religioso, pois os sujeitos têm liberdade em relação à autoridade das instituições e dos símbolos religiosos. A partir dessa ruptura, os jovens passam, cada vez mais, a ter diferentes formas de contato com o sagrado, o que também pode promover mudanças na forma de transmitir e relacionar-se com as vivências religiosas. Neste sentido, Camurça, Tavares e Perez (2015, p. 12) afirmam que,

A escolha individual apontaria para a privatização da religião, seu confinamento ao domínio do foro íntimo e, assim, levaria ao rompimento com os pertencimentos comunitários, logo para o desencantamento do mundo. Ao contrário, é graças à secularização, e por intermédio dela, que podemos relacionar-se de outro modo com a religião.

No caso da juventude, ir à missa, ao culto, participar de associações comunitárias e programações religiosas é, para muitos dos jovens, elemento importante de sociabilidade que contribui para formação de novos estilos de se portar adotados pela cultura juvenil no seu dia a dia, como na forma de expressar socialmente. Para a população jovem, a religião significa lazer, ou seja, inserir-se em outros referenciais culturais.

Os estudos de Novaes (2004) confirmam os conteúdos religiosos nas composições de letras em músicas de certos segmentos que se destacam na área das artes e cultura de rap e de hip-hop 
e que faz sucesso entre eles. Segundo Groppo (2000), a juventude seria um agente revitalizador da sociedade moderna por constituir elemento dinâmico de um tempo em permanente transformação, mesmo que suas atitudes sejam conservadoras ou liberais. Os jovens procuram evidenciar suas diferenças em relação aos adultos em busca de uma clara posição para se mostrarem distintos.

Em se tratando do âmbito religioso, nota-se um declínio no número do segmento juvenil que professa a mesma religião dos pais, numa evidência de que o fenômeno das religiões de "berço" está em queda/decaindo, mostrando um novo espaço que a religião ocupa no mundo contemporâneo. Os valores religiosos ganham credibilidade e valorização entre os jovens e, simultaneamente, promovem novos modos de ser no retrato da juventude. Apresentam-se, assim, como fundante na dimensão cultural como vários outros espaços, nicho de sociabilidade na vida dos jovens, e como também lugar que reverbera mudanças de fruição, principalmente nos finais de semana.

\section{Educação e Religião: campos em disputa}

No Brasil, a educação é um direito garantido no Art. 205 pela Constituição Federal de 1988 (BRASIL, 1988). Com a consagração desse direito, o Poder Público, o Estado, passou a ter formalmente responsabilidade, obrigação de garantir e ofertar educação de qualidade a todos os brasileiros e estrangeiros residentes no país. A lei máxima em vigor também traz no artigo 208, o teor da obrigatoriedade do ensino em instituições públicas, bem como assegura ao cidadão sua plena gratuidade. Assim, o dever do Estado com a educação será efetivado mediante a garantia de: I - ensino fundamental, obrigatório e gratuito, assegurado, inclusive, sua oferta gratuita para todos os que a ele não tiveram acesso na idade própria [...].

Além da Carta Magna que estabelece os princípios e prevê os direitos assegurados em seus dispositivos constitucionais, tem-se a atual Lei de Diretrizes e Bases da Educação - LDB de 1996. Esta é a legislação que define e regulamenta o sistema educacional, público ou privado, no território brasileiro em todos os níveis de ensino e também os recursos orçamentários destinados à educação. Importante ressaltar que esta Lei consagra, no artigo 33, orientações do Ensino Religioso ministrado nos estabelecimentos de educação pública, a qual declara explicitamente o caráter laico desses espaços e a proibição de privilegiar uma dada religião, visto que:

o ensino religioso, de matrícula facultativa, é parte integrante da formação básica do cidadão e constitui disciplina dos horários normais das escolas públicas de Ensino Fundamental, assegurado o respeito à diversidade cultural religiosa do Brasil, vedadas quaisquer formas de proselitismo. (BRASIL, 1988).

Sendo assim, evidencia-se no texto a laicidade do Estado democrático, com o objetivo de garantir a igualdade e a liberdade religiosa de seus cidadãos. A vigente Constituição Federal, em seu artigo 5o, incisos VI, VII e VIII, sacraliza-se a liberdade de crença e de culto, com a separação entre Igreja e o Estado, o qual deve manter-se absolutamente neutro. Ela dispõe no inciso VI que "é inviolável a liberdade de consciência e de crença religiosa, sendo assegurado o livre exercício dos cultos religiosos e garantida, na forma da lei, a proteção aos locais de culto e as suas liturgias".

As contradições apresentadas por Machado (2005), que se constituem no campo escolar, expressam dois movimentos dialéticos que ocorrem nesse espaço. Ao mesmo tempo em que há forças de controle para a legitimação de bens produzidos para a manutenção da tradição, há o movimento herético de contestação às regras e posições. Se por um lado a garantia da laicidade por meio de leis constitucionais foi um movimento de transformação do campo, por outro, a disputa para a ruptura dessa regra é constante no campo quando se impõe uma determinada visão religiosa que se sobrepõe às demais. 
Nesse sentido, trava-se uma contenda entre religiões no espaço escolar. Essa é manifestada por meio de intolerância religiosa, preconceito, agressões e desrespeito. É a disputa de poder do campo religioso no campo escolar, ainda que, em lei, garanta-se a laicidade e o reconhecimento de culturas afrodescendentes e indígenas, que ultrapassam a dimensão do folclórico. Esses são grandes desafios colocados à escola na atualidade com a implementação de políticas afirmativas de reconhecimento de minorias, a partir, por exemplo, das leis supracitadas. Estas políticas desestabilizam o campo escolar quando, com a ampliação das oportunidades educativas, novos sujeitos adentram o espaço escolar, muitas vezes, "empoderados" por estas políticas e/ou silenciados pelos atos de intolerância.

Assim como o campo escolar, o religioso tem passado por muitas mudanças com novos desenhos do fenômeno religioso, que trazem estratégias de visibilidades dos segmentos perante o olhar público, no entanto, "a religião da escolha pessoal suscita mudanças que afetam e fragiliza limites, desde a autoridade vinculante dos sistemas religiosos, ao grau de comprometimento com esta ou aquela instituição" (CASTRO; CAVALCANTE; JUBÉ, 2016, p. 9). Este novo movimento de transformação na tradição religiosa nos remete à perda do monopólio das instituições religiosas, visto que, ao longo da história, principalmente, o Cristianismo exerceu soberania absoluta no campo das religiões em relação às outras manifestações religiosas, no mundo ocidental.

Nesse cenário atravessado por disputas com diferentes modalidades de experiência com o sagrado, constata-se uma explosão do fenômeno religioso, com número expressivo de pessoas transitando de uma religião a outra e tendo duplo pertencimento nos movimentos religiosos. Segundo Bourdieu (2004, p. 122), assiste-se, assim, "uma redefinição dos limites do campo religioso, à dissolução do religioso em um campo mais amplo, que se acompanha de uma perda do monopólio da cura das almas no sentido antigo".

A escola, como espaço laico em que culturas diversas se entrecruzam, tem como função acolher a diversidade, educar as gerações futuras e ensinar conhecimentos científicos com o intuito de transformação social e emancipação. Quando se trata da relação jovens e escola, a literatura vem sinalizando um distanciamento entre as culturas juvenis e a dinâmica escolar em seus espaços de sociabilidades que são permeados por tensões, conflitos geracionais e dilemas juvenis, tornando-os um dos aparelhos ideológicos mais eficientes da manutenção social. "É, enfim, a lógica própria de um sistema que tem por função objetiva conservar os valores que fundamentam a ordem social" (BOURDIEU, 2014, p. 63).

Ao enfocar a relação entre juventude e escola, temos observado como campos de reflexão, de inúmeros estudos, sob os múltiplos olhares, de diferentes abordagens epistemológicas, autores(as) como, Spósito (2012); Novaes (2012) e Carrano (2009); Camacho (2004) e Dayrell (2010), dentre tantos outros, tencionam seus estudos para a importância de construir pontes entre as manifestações culturais juvenis e a instituição escolar como possibilidades de diálogos. No entendimento de Dayrell (2010, p. 1):

Denominar o sujeito da ação educativa como jovem implica no reconhecimento de que o aluno, ao chegar à escola, traz consigo uma diversidade sociocultural expressa na fase da vida na qual se encontra, com suas demandas e necessidades específicas, mas também na origem social e respectiva cultura, no gênero, no pertencimento étnico-racial e nas experiências sociais vividas, que interferem direta ou indiretamente nos modos como cada jovem vai lidar com a sua escolarização e construir sua trajetória escolar.

A escola, como espaço heterogêneo, transforma-se num campo de tensões e conflitos, mais especificamente, quando os jovens trazem consigo as vivências, as concepções de mundo, as tradições religiosas adquiridas no contexto familiar e nas instituições religiosas e, sobretudo, chocam com a cultura veiculada e legitimada pela escolar. Apesar da reconhecida importância de seu 
papel na estrutura social, a escola tem demonstrado pouco interesse por esses saberes culturais que permeiam seus espaços e tempos escolares. Bourdieu (2014, p. 63) adverte que:

O que está implícito nessas relações com a linguagem é todo o significado que as classes cultas conferem ao saber erudito e à instituição encarregada de perpetuá-lo e transmiti-lo. São as funções latentes que essas classes atribuem à instituição escolar, a saber, organizar o culto de uma cultura que pode ser proposta a todos, porque está reservada de fato aos membros das classes às quais ela pertence.

A relação estabelecida entre estudantes e universo escolar é marcada por descompassos, vivenciados por eles neste campo, que negligencia seus saberes, seu modo de ser e agir fora do espaço escolar. Nessa lógica, segundo Bourdieu (2014, p. 65) "a instituição é encarregada da conservação e da transmissão da cultura legítima de exercer suas funções de conservação social". Como instância educativa, também, a escola tem suplantado a voz das frações populares, apesar de ser um lugar ao qual o grupo juvenil provavelmente gostaria de frequentar, que valoriza e consagra uma dada cultura sancionada como válida nos espaços multiculturais, em detrimento de "ainda não reconhecer as culturas juvenis como possibilidades de inclusão e transformação. É exatamente isso que tais culturas (re) clamariam: inclusão, reconhecimento e pertença" (CARRANO, 2009, p. 192).

Nesse campo de relações de aparências pacíficas, os agentes envolvem-se constantemente em situações conflitantes, em embates que ocorrem no âmbito escolar, quando surgem questões que suscitam polêmicas sobre futebol, religião, política, entre outras. Segundo Castro, Cavalcante e Jubé (2016, p. 5),

Nesse clima de tensões latentes, o docente utiliza-se estrategicamente, suas convicções legítimas em restabelecer a ordem, promovendo entre os pares, relações em contínuas trocas de conhecimentos, diálogos e também negociações em função da lógica de um sistema que tem legitimidade de conservar os valores que fundamentam a ordem vigente.

No campo escolar, o olhar para o diverso gera situações conflitantes e tensões entre professores e alunos e quando a diversidade religiosa se apresenta, às religiões afro-brasileiras saem de seus redutos sagrados de manifestações ritualistas próprias, os terreiros, e adentram a escola, ela transforma-se num campo de disputas, embates, reprodução e enfrentamento de preconceitos e, sobretudo, atitudes correlatas de intolerância religiosa contra as religiões de matriz africana. $\mathrm{O}$ espaço dito laico, por conseguinte, sinaliza dificuldades de lidar com a diversidade, ou seja, nesse caso, com a cultura religiosa dos(as) jovens de terreiros que frequentam esse lugar. Em relação a isto, Caputo (2012, p. 197) sinaliza que:

A maioria dos praticantes desta religião, ao serem discriminados, sente vergonha e inventam formas de se tornarem invisíveis. A principal delas é esconder os artefatos religiosos, os preceitos do culto, a fé e a cultura. Isso acontece em diversos espaços, mas, a escola é o 'pior deles'.

É imprescindível que a ação pedagógica encontre ferramentas humanizadoras que deixem de "invisibilizar" o jovem ou reconhecê-lo de maneira homogeneizadora, para que, assim, ele passe a ser aceito efetiva mente como sujeito de direito. É interessante mencionar que a invisibilidade ocorre também em outro desdobramento, pois os jovens que frequentam os terreiros de candomblés com intuito de camuflar seu pertencimento religioso e adereços que compõem a mística cultural, utilizam este artifício para serem aceitos nos grupos, na vizinhança e, principalmente, dentro da escola. Além disso, a invisibilidade está atrelada a insultos racistas, preconceitos, dentre outros adjetivos da intolerância que afetam, principalmente, os praticantes desta religião. Caputo (2012, p. 186) 
pontua que "já na escola, eles escondem a fé e inventam formas de invisibilidades para não serem discriminados". Corroborando com essa ideia, Novaes (2011, p. 275) argumenta que:

\begin{abstract}
Muitos jovens entrevistados - como em gerações anteriores, continuam se definindo como católicos, sem deixar de ir a centros e a terreiros. Este fenômeno, bem conhecido entre nós, revela estratégias de apresentação social ante os preconceitos e perseguições sofridos pelos adeptos das religiões afro-brasileiras ao longo da história, mas também de 'duplo pertencimento', que fazem com que um pai ou uma mãe de santo possam dizer, que sem constrangimento: 'Sou católica e da umbanda' ou 'sou católica e do santo'.
\end{abstract}

Na tentativa de entender os meandros que acontecem no interior da escola, na condição de agente socializador e de práticas culturais, e propulsora dos processos formativos, passa a lidar com um conteúdo que, para ser trabalhado, exige um novo olhar. Dentre eles, assinalo a inclusão das religiões afro-brasileiras como tema a ser contemplado na implementação da Lei 10.639, em 2003, na qual se assegura como obrigatório o ensino da História e da Cultura Afro-brasileira em estabelecimentos públicos e particulares, ensino fundamental e médio. É neste contexto emblemático que os atores em instituições escolares precisam articular práticas que deem sentido para a escola em suas vidas, tendo em vista estreitar laços entre o espaço dito laico, a escola, e as crenças, valores e as culturas juvenis vivenciadas por eles, em seus multifacetados contextos fora do ambiente escolar.

Para romper com a conservação do campo escolar, a Lei n. ${ }^{\circ}$ 10.639/03 institui a relevância da aplicabilidade para a Educação das relações Étnico-raciais, para a efetivação de ações pedagógicas significativas, que auxiliem o conviver e respeitar as diferenças. Pela lei, a escola pública é laica, gratuita e obrigatória, e a função de uma educação que se pretende ser democrática, deve combater os atos de violência simbólica que desqualificam e estigmatizam os praticantes das religiões de influência africana, seus credos e práticas religiosas. Este espaço de sociabilidade constitui-se, potencialmente, em um lugar privilegiado para a superação das tensões entre os campos educacional e religioso e no combate de preconceitos raciais à diversidade religiosa que se encontram presentes em seu interior.

Cabe destacar que os episódios de ataques aos adeptos das religiões afro-brasileiras e seus templos sagrados, como também o desrespeito velado nas atitudes preconceituosas e a violência de todas as formas sofrida por eles, dentro e fora da escola, para Hannah Arendt (1994), chama-se de violência, um ato banal, deflagrado contra alguém, mas sempre com vistas a outra demanda do que a violência em si. Assim, o campo escolar tem-se mostrado resistente às diversas manifestações culturais e/ou religiosas que não legalmente reconhecidas e contempladas nos conteúdos curriculares a despeito das leis para assegurar a aplicabilidade do ensino de História e Cultura Afro-brasileiras.

\title{
Experiências de jovens de terreiros no chão da escola: tensão no campo escolar e estratégias de resistência
}

Os jovens de terreiros, participante da pesquisa (cujos nomes são doravante usados são Equede, Ogã Alabê, Ogã Rodante, Ogã Jovem, Iaõ e Abiã), enumeraram um conjunto de casos que configuraram cerceamento de manifestar seu credo religioso, desde os conhecimentos apreendidos no terreiro, até a utilização das indumentárias que fazem parte dos preceitos da religiosidade, em distintos espaços sociais, tais como: na escola, nas ruas, nos estabelecimentos públicos, no meio familiar, nos âmbitos de trabalho. Estes eventos têm aumentado assustadoramente no Brasil e em todos os estados brasileiros. Os dados da pesquisa desenvolvida em 2016, o Relatório de Intolerância Religiosa no Brasil, segundo as fontes de informações colhidas da Secretaria de Direitos Humanos (SDH), revelam denúncias de discriminação que compreendem os períodos de 2011 a 2015. Nesse 
espaço de tempo, foram registrados, mais especificamente no Distrito Federal, a quantidade de 25 casos de prática de discriminação denunciadas.

Tal ataque às experiências religiosas dos grupos minoritários quando adentram o espaço dito laico, a escola, são comuns. Esse tipo de violência e qualquer outro tipo de discriminação, que exclui a grande maioria da população no país, de seus direitos, é recorrente socialmente no Brasil. O que, por sua vez, passa despercebido ou, então, não é tratado com a devida atenção, enquanto hostilidade simbólica sofrida. Para Cavalcanti (2016), o âmbito escolar "dito laico" "deveria ser o lugar de formação de um cidadão que preza pela justiça e igualdade, e não ser o ambiente formador de desigualdades e desrespeitos" (p. 72). Os jovens de terreiro da pesquisa revelam tal descriminação quando afirmam em suas falas.

Os adereços e as vestimentas fazem parte da religião desses jovens e ao se manifestarem por estes símbolos e signos, os jovens relatam hostilidade na comunidade escolar. Segundo Abiã, a tentativa de recriminá-lo por conta do turbante o levou a denunciar o agressor visto que o jovem tem conhecimento das leis que protegem a diversidade religiosa no país: "a gente foi lá e denunciou, porque viu que não era brincadeira, porque agora a gente entende, graças a Deus, uma lei que nos defende. [...] Quando eu era bem mais pequenininha aí os outros já até bateram na gente já, minha mãe já tinha ido na escola já, também, falar" (Abiã).

Outro jovem, Equede, lembra que ao dizer que aos fins de semana costuma ir ao Candomblé por isso não podia sair com os amigos no fim de semana, os mesmos ridicularizavam e não acreditavam na sua fala: "Só depois que eles viram que eu postei foto, eles acreditaram, no Facebook. [...] Eu falava na escola, sou candomblé. Ah, isso é coisa de macumba, demônio, eu falava não, sou do candomblé" (Equede).

Ogã Alabê, que no momento da pesquisa já estava cursando ensino superior, lembra-se de momentos incômodo na escola por uma colega de religião diferente:

[...] eu estudava com uma moça, ela era crente fervorosa, sabe? Mas é daquela sabe? Crente fervorosa, mas era daquela acho que Universal, porque criticava o tempo todo. Aí teve um belo dia, que eu coloquei ela no lugar dela, aí ela acordou, mas é lógico, ela tinha a opinião dela, e eu tinha a nossa opinião [...] você tá criticando, você tá falando de algo que você não conhece, entendeu? (Ogã Alabê).

Enquanto alguns falam abertamente sobre a sua religião no espaço escolar, outras se sentem intimidadas como o Ogã Jovem: "Antes eu (falava que eu) era cristão, hoje eu falo, sou do candomblé". A partir de políticas públicas que garantem a expressão da religiosidade em espaços públicos, os jovens, apesar dos preconceitos e ataques à religião de matriz africanas, sentem-se amparados legalmente para o enfrentamento de tais situações.

Ogã Rodante prefere não comentar sobre a sua religião fora de casa, mas se perguntam na escola, o jovem diz que não tem vergonha de dizer que é do Candomblé, mas também admite que nunca comentou sobre a religião no espaço escolar. "[...] Não, na escola eu nunca, nunca comentei sobre religião que eu sou na escola, não” (Ogã Rodante).

Iaô apresenta outra narrativa que revela o preconceito: "na escola os colegas sempre fez piadinhas, porque eu falava que era do candomblé, e eu falava mesmo. [...] Preconceito todo mundo sofre, sim. Eu sofro muito por todas as razões: sou negro, da classe pobre, homossexual, e do candomblé, nem tô nem aí, quem quiser que fale, não ligo para isso" (Iaô).

As falas dos jovens são reveladoras, pois trazem, em primeiro lugar, a importância do ambiente escolar nestes casos de intolerância religiosa, como "instância privilegiada de reflexão e problematização" (BRASIL, 1988). É desta tarefa que a escola foi incumbida na sociedade, como agência formadora, capaz fomentar transformações sociais na sociedade e traçar ações com respaldo legal para implementação de uma educação para a diversidade. Para jovens de terreiro, 
constrangimentos e ofensas em suas escolas, lugares legítimos de sociabilidades são regulares, sendo que nestes lugares se deveriam compartilhar os saberes que circulam nos terreiros, como lugar de vivências, de experiências e, sobretudo, processos formativos, que saem dos tempos sagrados, terreiros e adentram o espaço dito laico.

A narrativa destes episódios permite estabelecer ainda que os jovens de terreiro elaboraram estratégias de enfrentamento para lidar com as situações de violência simbólica e física da religião de matriz africana, com o preconceito e com a discriminação que convivem diariamente.

Outro caminho apontado no enfrentamento às situações discriminatórias pelos jovens são as orientações do Pai de Santo que consiste na estratégia de "fuga" do embate com o discurso do opositor: "Se alguma pessoa chegar, tipo, vira as costas e vai embora, não se pelo fato da polícia, dá um processo. Mas eu não gosto muito, porque guerra só gerencia guerra, né? Aí eu também fico do lado de fora, eu num gosto" (Ogã Jovem). O distanciamento dos sistemas educacionais em relação à vertente religiosa que estes jovens de terreiro trazem para o interior da escola, a qual é ao mesmo tempo legitimada e deslegitimada. Em respostas a essas questões, Cavalcanti (2016, p. 62) assim se posiciona:

Para se pensar também até que ponto a educação pública não tem falhado no que diz respeito à compreensão de que religiosidade também é uma forma de expressão cultural, cabendo aos profissionais de diversos campos, entre outros o da História e das Ciências Sociais, contribuírem com seus saberes na busca de alternativas para a minimização dos impactos das diferentes formas de intolerância na dignidade do ser humano.

As políticas públicas, sobretudo, as políticas afirmativas, por meio da Lei no 10.639 de 09 de janeiro de 2003, que determina a obrigatoriedade do ensino da História e Cultura Afro-Brasileira e Africana nos estabelecimentos públicos e particulares, no ensino fundamental e médio, foi sancionada com intuito de combater atitudes discriminatórias, o racismo e o preconceito. A referida Lei pode ser considerada como um caminho que proporciona avanços no sistema educacional brasileiro, cultural e, sobretudo, pode ser considerada um viés também de mudanças em ações sociais humanas e que reconhece o que os jovens de terreiro podem trazer com os saberes que circulam nos terreiros para o espaço dito laico, no sentido de reflexões e discussões da importância de sua cultura religiosa, assim como para desconstruir práticas preconceituosas em relação à sua religião de influência africana. Logo,

A escola é também um espaço educativo em sentido amplo: tem a extraordinária tarefa social de criar intencionalmente as condições educativas para que possamos receber, desconstruir e reconstruir o mundo humano já construído. (DIAS, 2012, p. 9).

Assim, o âmbito educacional tem um grande desafio pela frente de criar práticas pedagógicas que reconheçam o respeito e a relevância dos africanos e afrodescendentes na constituição do país. Com as alterações na Lei de Diretrizes e Bases da Educação (LDB) no 9.394/96, pela nova legislação da Lei 10.639/03 sancionada, foi preciso o Governo Federal fazer implementações de várias ações para assegurar o teor da referida lei, tais como: aprovação das Diretrizes Curriculares Nacionais para a Educação das Relações Étnico-Raciais para o Ensino da História e Cultura Afro-Brasileira e Africana (Parecer CNE/CP no 03 de 10 de março de 2004); e a Publicação da Resolução CNE/CP no 01 de 17 de junho de 2004 que trata dos direitos dos entes federados na parceria perante a Lei supracitada.

Para materialização desta Lei, faz-se necessário o seu conhecimento pela sociedade civil, a qual deve estar imbuída neste processo construção e desenvolvimento de ações, bem como práticas em relação ao "diferente", para se atender as determinações que estão expressas na nova legislação em relação à Educação das Relações Étnicas-Raciais e à LDB 9.394/96. 
É por meio do modo apresentado ao longo deste estudo que os jovens de terreiros vivenciam situações de enfrentamento à sua condição religiosa tanto no espaço público, como na cidade, e no espaço escolar. Ambos são espaços hostilizadores de manutenção da ordem estabelecida e que rechaçam toda e qualquer posição que desestabilize as regras do campo. Estes jovens são dotados de conhecimentos das regras do campo escolar, tanto constituídas nas sociabilidades juvenis quanto nos processos formativos que ocorrem nos terreiros. O pai de santo, como mentor desses jovens, conhecendo bem o campo, ensina as estratégias de sobrevivência para lidarem com a intolerância e o preconceito. São estratégias, muitas vezes que potencializam a invisibilidade da cultura do candomblé, mas também resguardam os adeptos de possíveis violências que podem ocorrem pelo simples fato de serem jovens de terreiro.

\section{Considerações finais}

A pesquisa versou sobre jovens de terreiros no chão da escola e suas tensões e resistências. O intuito do estudo é possibilitar a outros leitores e acadêmicos um ponto de vista sobre a relação entre a escola, como um espaço laico, e jovens provenientes de religiões não dominantes no espaço social, como o Candomblé. O diálogo estabelecido com os jovens do terreiro e a literatura sobre juventude, escola e religião proporcionou um conjunto de reflexão e proposições sobre um tema que é pouco discutido ou pesquisado, como demonstraram os estudos preliminares a este. Espera-se que este estudo contribua para a desconstrução, por vezes, negativa em relação às juventudes de religiões afro-brasileiras, sobretudo, no espaço escolar que, por sua vez, não cumpre o princípio da laicidade uma vez que é orientada pela legislação brasileira.

O Candomblé permeia distintos âmbitos da cultura brasileira, desde as artes plásticas, à culinária, à literatura, ao cinema, à música popular brasileira, até os blocos afro-carnavalescos e isto demonstra sua relevância para formação cultural deste país. Vale ressaltar ainda que ser uma religião minoritária não significa que ela seja menos importante enquanto manifestação religiosa ou que mereça menor no cenário de visibilidade das religiões.

Mesmo reprimida, proibida, perseguida por policiais e apontada como prática de "feitiçaria", "curandeirismo" e "charlatanismo" e tendo os templos sagrados como alvo de destruição e desqualificação, ela resiste. Nos dias atuais, os adeptos e praticantes também utilizam mecanismos que a mascaram e a escondem atrás de outras denominações religiosas legitimadas pela classe dominante.

Mesmo tido como um país laico, o Brasil desenvolve uma espécie de manobra para deslegitimar religiões de matrizes africanas. Nessa lógica, tendo em vista seus depoimentos, os jovens de terreiro pesquisados vivenciam situações de enfrentamento à sua condição religiosa no espaço público, na cidade no geral, e no espaço escolar, pois, ambos são espaços hostilizadores, de manutenção da ordem estabelecida e rechaçadores de toda e qualquer posição que desestabilize as regras do campo.

Nos relatos dos jovens, constatamos que eles não ocultavam sua religiosidade, caso alguém perguntasse, mas preferiam não ficar falando sobre isso abertamente e sem necessidade. Em situações similares, quando abordados ou questionados com relação à sua religião, alguns jovens relataram que "batiam em retirada" e, por isso, não costumavam entrar em discussões. Também grande parte dos jovens de terreiro já sofreu algum preconceito explícito por parte de pessoas e/ou velado, muitas vezes, com olhares de desdém, estranhamento com teor pejorativo. Há ainda casos narrados de jovens que não foram aceitos em outras denominações religiosas, em circunstâncias da orientação sexual.

Para o enfrentamento dessas tensões, os jovens de terreiros silenciam-se como estratégia no enfrentamento do preconceito à sua pertença religiosa, essa forma de enfrentamento passiva religiosa não os leva à constituição da autonomia de um discurso que apela para o discernimento, esclarecimento do opressor sobre sua religiosidade e ainda que ele reveja suas atitudes preconceituosas. 
Ao contrário, esse silenciamento seria uma forma de reprodução da exclusão social. E outra estratégia de resistência é recusar-se a problematizar a questão com seus pares uma vez que não se sentem seguros e temem por sua segurança evitando assim o confronto.

É neste espaço de silenciamento e de recua que a escola pode atuar como mediadora de situação de desconhecimento, intolerância religiosa e de preconceito para com os jovens de terreiros. A legislação garante duplamente a manifestação religiosa no espaço escolar por ela ser laica, portanto, não a compete impor ou negar uma e outra religião, mas esclarecer, apresentar, instruir as diferentes, por meio de conhecimentos culturalmente construídos e constituídos na e pela cultura, religiões, inclusive as de matrizes africanas, pois estas também estão garantidas pela Lei 10.639/03, que estabelece a obrigatoriedade do ensino de História da África e da Cultura Afro-brasileira nas escolas públicas e privadas, no ensino fundamental e médio, e sua aplicabilidade nesses espaços educativos que abrigam uma pluralidade de culturas e, por consequência, manifestações religiosas.

Nesse sentido, formar jovens para a cidadania e respeito às diferenças culturais, religiosas e sociais pressupõe promover leituras de mundo com a ampliação do repertório dos estudantes visto que muitos não têm outros espaços para conhecer a diversidade religiosa do nosso país. E em se tratando de jovens de terreiros, estes têm muito a contribuir para desmistificar as representações negativas da sua religião, pois se trata de jovens falando com e para jovens. As políticas educacionais são importantes para o rompimento de práticas discriminatórias no âmbito escolar, mas elas não são suficientes sem a vivência e sem a participação efetiva dos jovens envolvidos no processo, pois eles aprendem no coletivo, com seus pares, participando, debatendo e fazendo, características típicas da juventude.

\section{Referências}

ABRAMO, Helena Wendel. Condição Juvenil no Brasil contemporâneo. In: ABRAMO, Helena Wendel; BRANCO, Paulo Martoni (org.). Retratos da juventude brasileira: análises de uma pesquisa social. Condição Juvenil no Brasil contemporâneo. São Paulo: Fundação Perseu Abramo: Instituto Cidadania, 2012. p. 73-86.

ABRAMO, Helena Wendel. O uso das noções de adolescência e juventude no contexto brasileiro. São Paulo: Ação educativa, 2003.

ARENDT, Hannah. Sobre a violência. Rio de Janeiro: Relume - Dumará, 1994.

BOURDIEU, Pierre. A escola conservadora: as desigualdades frente à escola e à cultura. In: Escritos de Educação. NOGUEIRA, Maria Alice; CATANI, Afrânio (org.). Petrópolis: Vozes, 2014. p. 39-64.

BOURDIEU, Pierre. Coisas Ditas. Tradução Cássia R. da Silveira, Denise Moreno Pegorim. São Paulo: Brasiliense, 2004.

BRASIL. Ministério da Educação. Parecer CNE/CP3/2004, 10 de março de 2004. Diretrizes curriculares nacionais para a educação das relações étnico-raciais e para o ensino de História e Cultura Afro-brasileira e Africana. Brasília, DF: Ministério da Educação, 2004.

BRASIL. Ministério da Educação. Plano Nacional de Implementação das diretrizes curriculares para a educação das relações étnico-raciais e para o ensino de História e Cultura Afro-brasileira e Africana. Brasília, DF: Ministério da Secretaria Especial de Políticas de Promoção da Igualdade Racial, 2009.

BRASIL. [Constituição (1988)]. Constituição da República Federativa do Brasil: promulgada em 05 de outubro de 1988. São Paulo: Saraiva, 2015.

BRASIL. Lei no 9.394, de 20 de dezembro de 1996. Estabelece as diretrizes e bases da educação nacional. Diário Oficial da União: Seção I, Brasília, DF, v. 134, n. 248, p. 27834-27841, 23 dez. 1996.

CAMACHO, Luíza Mitiko Yshiguro. A invisibilidade da juventude na vida escolar. Perspectiva, Florianópolis, v. 22, n. 2, p. 325-343, jul./dez. 2004. 
CAMURÇA, Marcelo Ayres; TAVARES, Fátima; PEREZ, Léa. Religião, pertenças, crenças e valores na juventude de Minas Gerais. Paralellus, Recife, v. 6, n. 13, p. 407-428, jul./dez. 2015.

CAPUTO, Stela Guedes. Educação nos terreiros: e como a escola se relaciona com crianças de candomblé. 1. ed. Rio de Janeiro: Pallas, 2012.

CARRANO, Paulo Cesar Rodrigues. Identidades Culturais juvenis e escolas: arenas de conflitos e possibilidades. Diversia Educación y Sociedad, Chile, n. 1, p. 159-184, abr. 2009.

CASTRO, Cláudia Maria de Jesus; CAVALCANTE, Cláudia Valente; JUBÉ, Milene de Oliveira. Tensões entre o campo da educação e o religioso: uma disputa de conservação do campo. 2016. In: SIMPÓSIO INTERNACIONAL DE HISTÓRIA DAS RELIGIÕES, 2., 2016, Florianópolis. Anais [...]. Florianópolis, 2016. Disponível em: http://www.simposio. abhr.org.br/resources/anais/6/1473992798_ARQUIVO_Artigo- ABHR.pdf. Acesso em: 20 abr. 2017.

CAVALCANTI, Juliana Batista. Pelo ensino das religiosidades, reflexóes sobre o ensino religioso e sobre o silêncio dos historiadores e cientistas sociais. In: SANTOS, Babalawô; NASCIMENTO, Maria das Graças O.; CAVALCANTI, Juliana B. M. T.; ALMEIDA, Mariana Gino Vítor (org.). Intolerância religiosa no Brasil: relatório e balanço. Rio de Janeiro: Klíne: CEAP, 2016. p. 62-82.

DAYRELL, Juarez. Juventude e escola (relação juventude e escola). In: OLIVEIRA, Dalia Andrade; DUARTE, Adriana Maria Cancella.; VIEIRA, Lívia Maria Fraga. Dicionário: trabalho, profissão e condição docente. Belo Horizonte: UFMG/Faculdade de Educação, 2010. CD-ROM.

DAYRELL, Juarez. O jovem como sujeito social. Revista Brasileira de Educação, Rio de Janeiro, n. 24, p. 40-53, set./dez. 2003.

DIAS, Dylia Lysardo. Senso comum e estereotipia nas práticas de leitura. Inter-Ação, Goiânia, v. 37, n. 1, p. 27-36, jan./jun. 2012.

FREITAS, Oliveira Ricardo. Jovens de terreiros: Ciberatismo e protagonismo juvenil entre integrantes de religiões afro-brasileiras em Salvador e região metropolitana. Educere et Educare, Cascavel, v. 10, n. 20, jul./dez. 2015.

GROPPO, Luís Antônio. Juventude: ensaios sobre a sociologia e história das juventudes modernas. Rio de Janeiro: DIFEL, 2000.

MACHADO, Maria Cristina Gomes. Manifesto dos Pioneiros da Educação Nova (1932) e a construção do sistema nacional de ensino no Brasil. In: ROSSI, Ednéia Regina; RODRIGUES, Elaine; NEVES, Fátima Maria (org.) Fundamentos históricos da educação no Brasil. Maringá: EDUEM, 2005. p. 111-128.

NOVAES, Regina. Juventude, percepções e comportamentos: a religião faz diferença? In: ABRAMO, Helena Wendel; BRANCO, Paulo Martoni (org.). Retratos da juventude brasileira: análises de uma pesquisa social. Condição Juvenil no Brasil contemporâneo. São Paulo: Fundação Perseu Abramo: Instituto Cidadania, 2012. p. 263-290.

NOVAES, Regina. Os jovens "sem religião": ventos secularizantes, "espíritos de época” e novos sincretismos. Estudos Avançados, São Paulo, v. 18, n. 52, p. 321-330, 2004.

PAIS, Machado José. A construção sociológica da juventude. Análise Social, Lisboa, v. 25, n. 105-106, p. 139-165, 1990.

SOFIATI, Flávio Munhoz et al. Juventude, religião e violência. In: ALVES, Flávia Miriam; MATUTINO, Aurisberg Leite (org.). Juventudes: educação e religião em cenários de violência. Goiânia: Editora Espaço Acadêmico, 2016. p. 66-94.

SPOSITO, Marilia Pontes. Algumas reflexões e muitas indagações sobre as relações entre juventude e escola no Brasil. In: ABRAMO, Helena Wendel; BRANCO, Paulo Martoni (org.). Retratos da juventude brasileira: análises de uma pesquisa social. Condição Juvenil no Brasil contemporâneo. São Paulo: Fundação Perseu Abramo: Instituto Cidadania, 2012. p. 87-128.

TAVARES, Fátima Regina Gomes; CAMURÇA, Marcelo Ayres. Religião família e imaginário entre a juventude de Minas Gerais. Numem: Revista de estudos e pesquisa da Religião, Juiz de Fora, v. 7, n. 1, p. 181, 2004.

URTEAGA, Maritza. La construcción juvenil de la realidade. Jóvenes mexicanos contemporâneos. México: Universidade Autónoma Metropolitana, 2011a. In: SIMPÓSIO NACIONAL DA ASSOCIAÇÃO BRASILEIRA DE HISTÓRIA DAS RELIGIÕES: SOCIABILIDADES RELIGIOSAS: MITOS, RITOS E IDENTIDADES , 11., 2009, Goiânia. Anais [...]. Goiânia: UFG/GT, 2009.

Data de submissão: 30/01/2021

Data de aceite: 03/02/2021 